\title{
Reformation and the end of Christendom: two visions
}

\author{
Eamon Duffy
}

Professor EAmon Duffy fba is Emeritus Professor of the History of Christianity at the University of Cambridge, UK, and Fellow of Magdalene College. A former member of the Pontifical Historical Commission, he sits on numerous editorial boards and advisory panels. His research centres on the history of late medieval and earlymodern popular religious belief and practice, and his most recent book is entitled Reformation Divided.

ed10000@cam.ac.uk

Cambridge, UK

This article reveals the complex dimensions which make it impossible to speak singularly of 'the Reformation'. Martin Luther's reforming activity gave rise to conflicting visions of the Church, which are impossible now to resolve. The article traces the trajectory of the English Reformation through the figures of Thomas More and William Tyndale. Although both convinced of the need for reform, More was opposed to Tyndale's approach, which he perceived would lead to the breakdown of order into anarchy. The outworking of this signals the end of Christendom, and has led to continuing mutual incompatibility.

REFORMATION • THOMAS MORE • WILLIAM TYNDALE • MARTIN LUTHER • DESIDERIUS ERASMUS • PROTESTANTISM 
The following journal article is a transcript of a lecture which was given at Wesley Church, Cambridge, UK, on 24 April 2017 to mark the rededication of Wesley House following its major refurbishment and building programme. Professor Duffy's lecture was accompanied by a number of images, some of which have been included here. The text reads largely as presented, in the hope that the texture and tone, and at times humour, of the content might be retained.

\section{Introduction}

It is very large minded of you to invite a dyed-in-the-wool Irish Roman Catholic to talk about the Reformation. I have given this talk the title of 'Reformation and the end of Christendom: two visions' because I want to reflect on the tragedy of conflicting visions in the sixteenth century about what Reformation might mean and I am going to home in on the radically opposed understandings of Reformation of two of the greatest figures of the sixteenth century - two great, good men, who it's not too much to say hated each other, Thomas More and William Tyndale. Towards the end of the talk, I also want to reflect on two opposing visions by two contemporary historians who take rather different views of the outcome of the Reformation.

Luther, of course, is the great figure we are commemorating this year, the 500th anniversary of his posting of his Ninety-Five Theses, which were an academic challenge to a rather sordid practice, the sale of the religious benefits known as indulgences to raise the money to build the new St Peter's. Selling indulgences was being farmed out across Europe with people taking cuts along the way. Luther's protest initially took the form of a public challenge to an academic debate on a swathe of arcane theological points. But this was the first age of print, and Luther was a publicist of genius. His list of topics for debate - the Ninety-Five Theses - was printed as a broadsheet, and although the legend that he nailed it to the door of the Castle Church is sadly probably not true, the Theses nevertheless became the world's most improbable bestseller. What might have been a technical academic exercise in the Wittenberg lecture hall rapidly escalated into a fundamental questioning of the whole theological underpinning of Western Christianity. In its wake, Europe divided roughly north and south - beer versus wine - and the peoples of Europe were pitched into a series of murderous ideological wars in which tens, possibly hundreds of thousands died and during which the religious, cultural and political map of Europe, and of the colonies which Europe was just 
beginning to acquire, was redrawn. We are still living with the consequences. This religious and cultural earthquake has traditionally been called the Reformation. It is a loaded term, which, as a practising Catholic, you can imagine I'm not altogether comfortable with. To call this religious revolution the Reformation implies that something that was broken got fixed and that a good form of Christianity replaced a bad one.

It is certainly true that Luther introduced aspects of Christianity which all the churches of the West now recognise as central. Luther was, above everything else, of course, a Bible translator. Luther triggered a religious revolution which focused on the Word of God in the vernacular and thereby initiated a transformation of Christian worship. His own reordering of Christian worship was extremely conservative. He reduced the number of sacraments to three and then two: essentially Baptism with Eucharist, and confession/penance as an option. But he didn't, for example, abolish the traditional Mass vestments, he continued to recommend the use of a crucifix in church, and he even used Latin in the Mass.

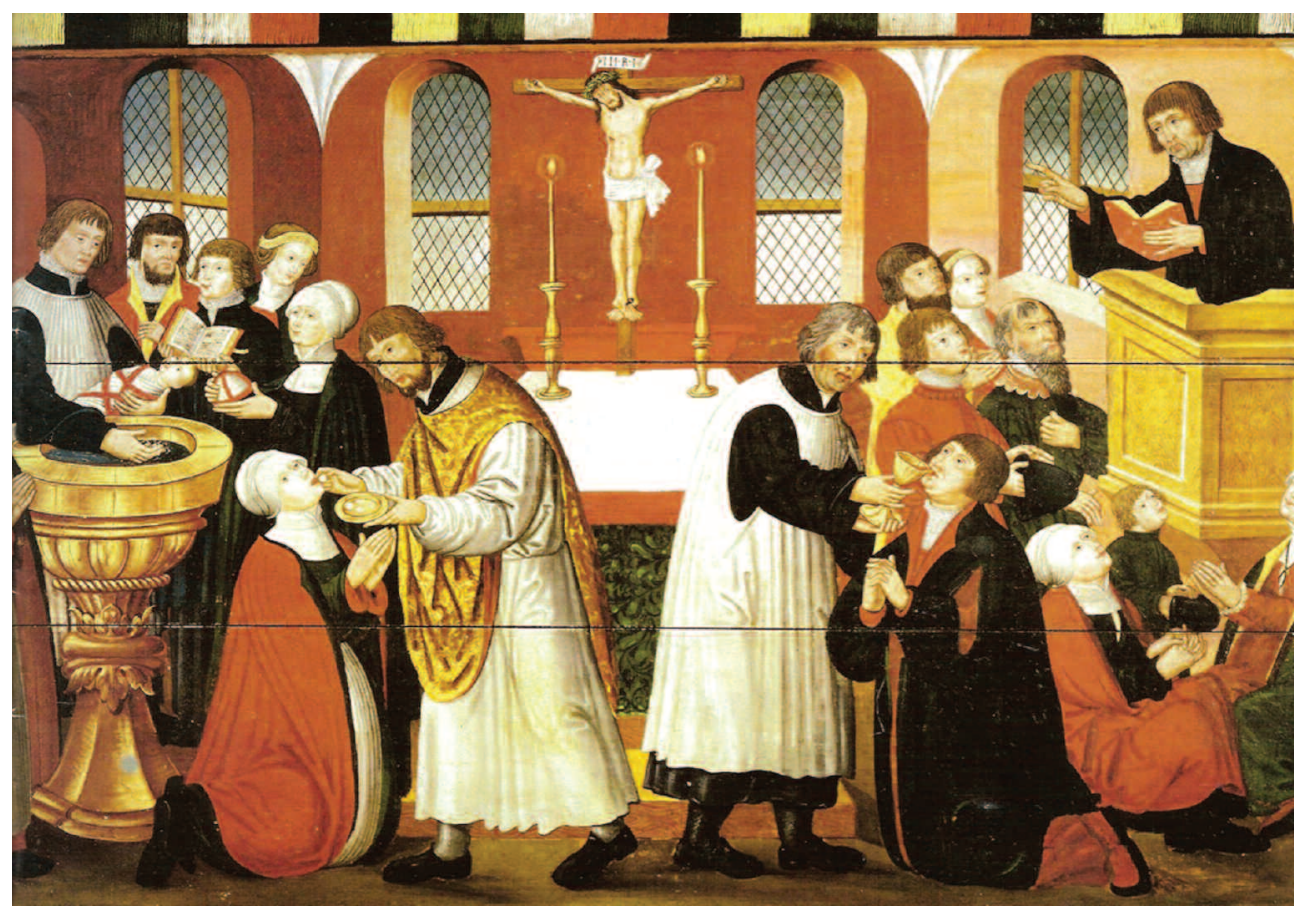

'Martin Luther preaching to the faithful' (1561, Church of Torslunde). Art Collection 2 I Alamy Stock Photo (rights purchased) 
However, the centrality of the Bible would inevitably and in a very short amount of time result in rather different kinds of worship. This is a painting of a Calvinist service in France about 15 or 20 years after Luther's death.

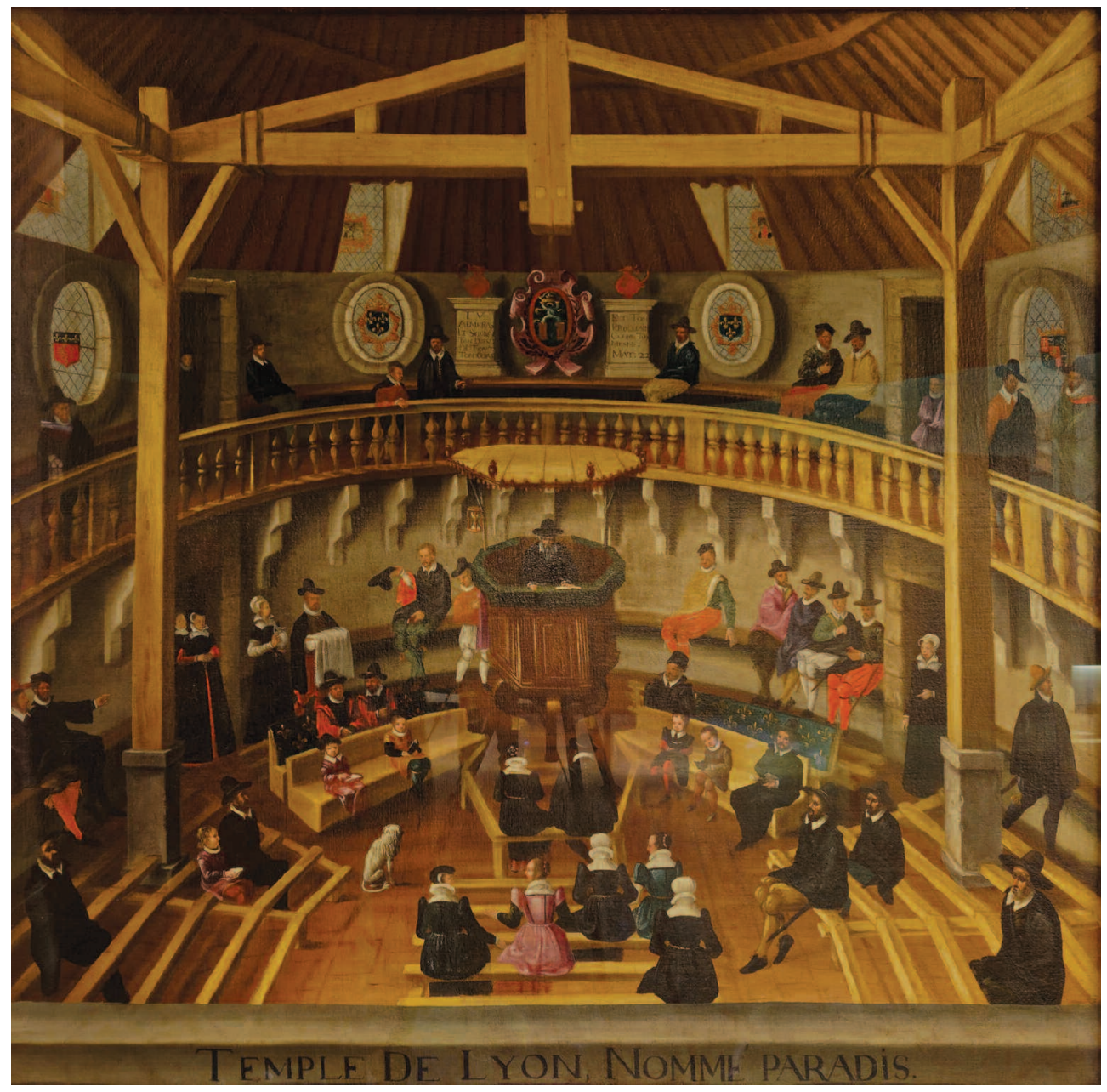

Jean Perrissin (1569-70), Le Temple de Paradis. Paul Fearn / Alamy Stock Photo (rights purchased)

As you can see, it's a very different kind of imagining of what a church should be: the pulpit central, with men, women and children sitting with their own Bibles following the preacher's words, and on occasion debating it, challenging, extending, making their own comments on it. Luther opened Pandora's box in a way that represents one of the great religious transformations, something that was to have incalculable consequences. 
At the heart of Luther's message was the affirmation of God's mercy, freely available to faith. That's an entirely positive message, but his message also had a very strong negative charge. When he encountered opposition from the ecclesiastical authorities, it involved very rapidly a denunciation of the traditional Church as no church at all. From the very early stages of Luther's protest, he harnessed print into this kind of negative comparison between Christ and the official Church. Here we have Christ washing his disciples' feet and the pope having his feet kissed.

Datfianal Cluifiti utu

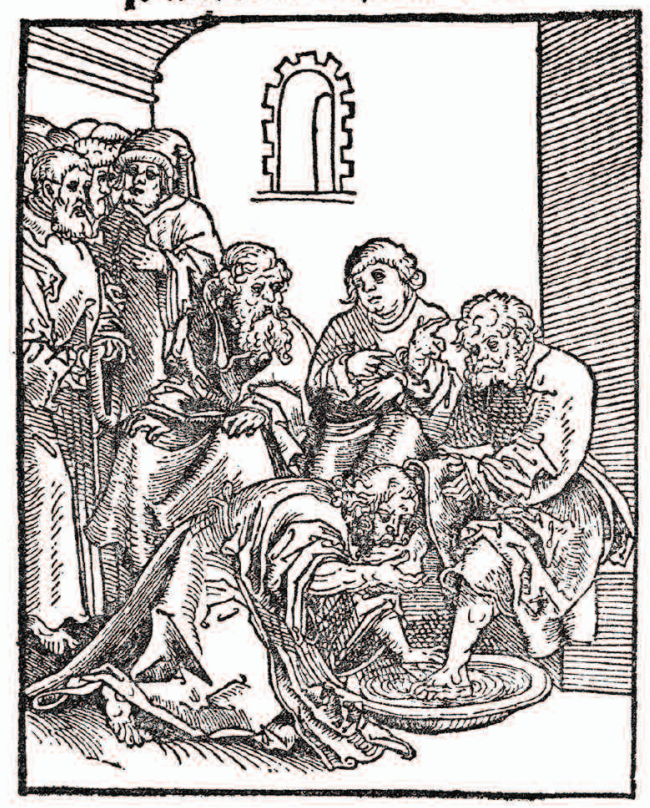

antiditutt.

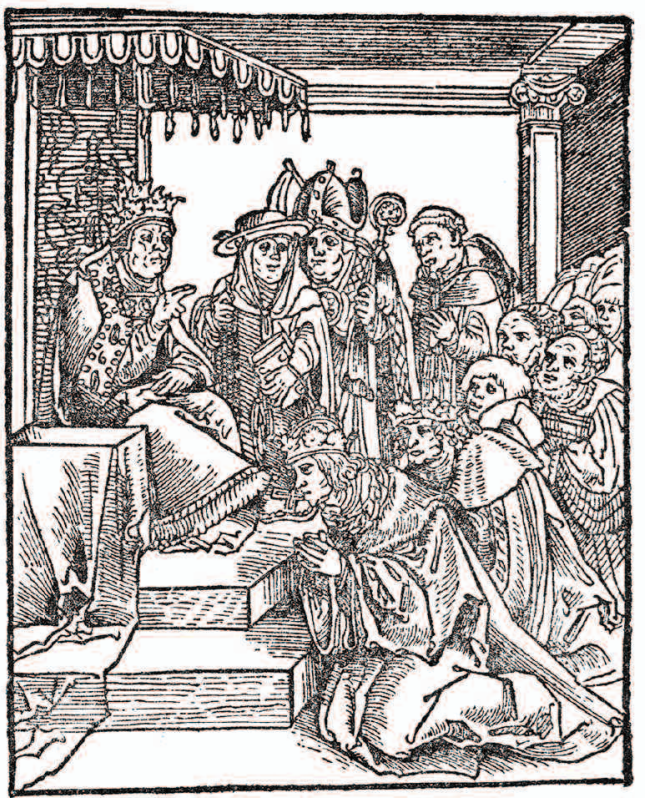

Anti-papal woodcut (c.1500). Granger Historical Picture Archive / Alamy Stock Photo (rights purchased)

The idea is that the pope is poles apart from what a Christian should be. That very rapidly turns really septic, with the identification of the papacy with Antichrist, very vividly evoked in these kinds of Reformation cartoons, and with identification of the official Church as anti-Christian. This is one of the illustrations from Luther's Bible, in which you see that the traditional figure of ecclesia becomes the whore of Babylon seated on the seven-headed beast with the kings of the earth worshipping her. 


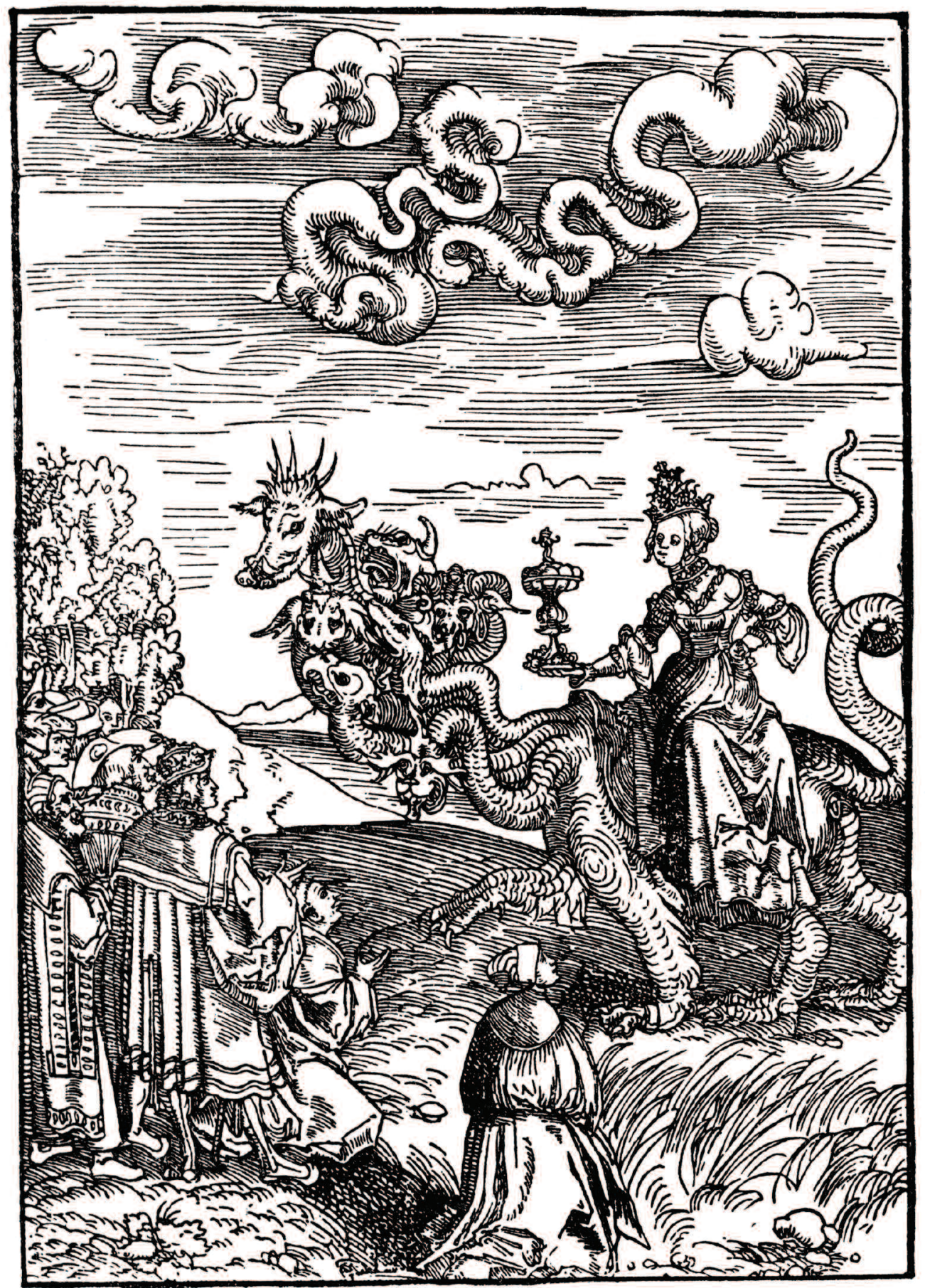

Whore of Babylon woodcut by Lucas Cranch the Elder (c. 1475-1553). from Luther's New Testament (1522). Interfoto / Alamy Stock Photo (rights purchased) 
Another print from the 1540s contrasts the worship of the true Church, rooted on Luther's preaching of Christ's merits, with monastic and papal preaching, coupled with the sale of indulgences and pleading the merits of the saints rather than of Christ. It's a very strong, clear negative message which demonises the Church at large, and centuries of the Church's past. Very quickly, then, Luther's Reformation takes the form of the disowning of huge tracts of the Christian past. It was implicit in Luther's declaration that if the Church found itself unable to accommodate his teaching of justification by faith alone, then that was too bad for the Church. It meant the Church was wrong. So we get this polarising, which is taken up all over the Reformation world. This is a picture which Henry VIII commissioned from an Italian painter Girolamo da Treviso, and it shows the four Evangelists stoning the pope to death.

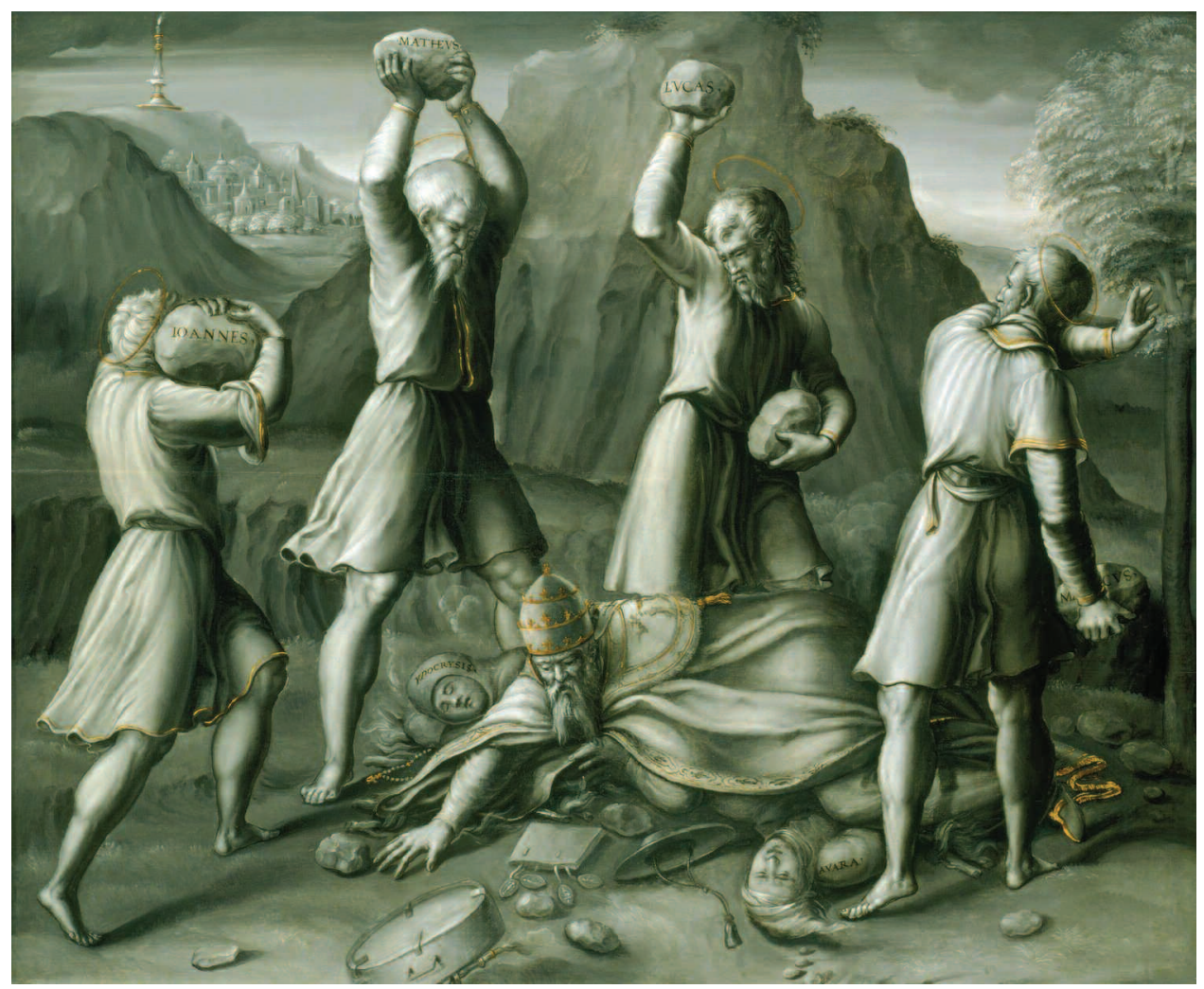

Girolamo da Treviso (active c. 1497-1544), A Protestant allegory (c. 1538-44). Royal Collection Trust / @ Her Majesty Queen Elizabeth II 2017 (permission given)

Many religious identities and communities emerged from this conflictual vision of Christendom: Lutheran, of course; and then Calvinist; later on, Anglican; many more radical groupings which are often lumped together under the 
name Anabaptist. These, along with the other groups that subsequently emerged - Presbyterians, Congregationalists, Shakers, Quakers, Mennonites, Amish, Pentecostalists and, yes, even Methodists - shared some beliefs and attitudes in common. They all prioritised the written word of God in the Bible over the traditional Church's teaching and discipline. They all vehemently rejected the papacy and the allegedly materialistic religious system which the papacy headed. But they were divided among themselves - often lethally divided - on almost everything else. Within a single generation of Luther's protest, Protestants were excommunicating, fighting and persecuting each other, as well as the common Catholic enemy, and many were calling for a reform of the Reformation. So what characterises the religious transformations of the sixteenth century and their outworkings in the centuries that followed is not a single unifying energy - good or bad, the Reformation - but rather variety and multiple incompatibilities.

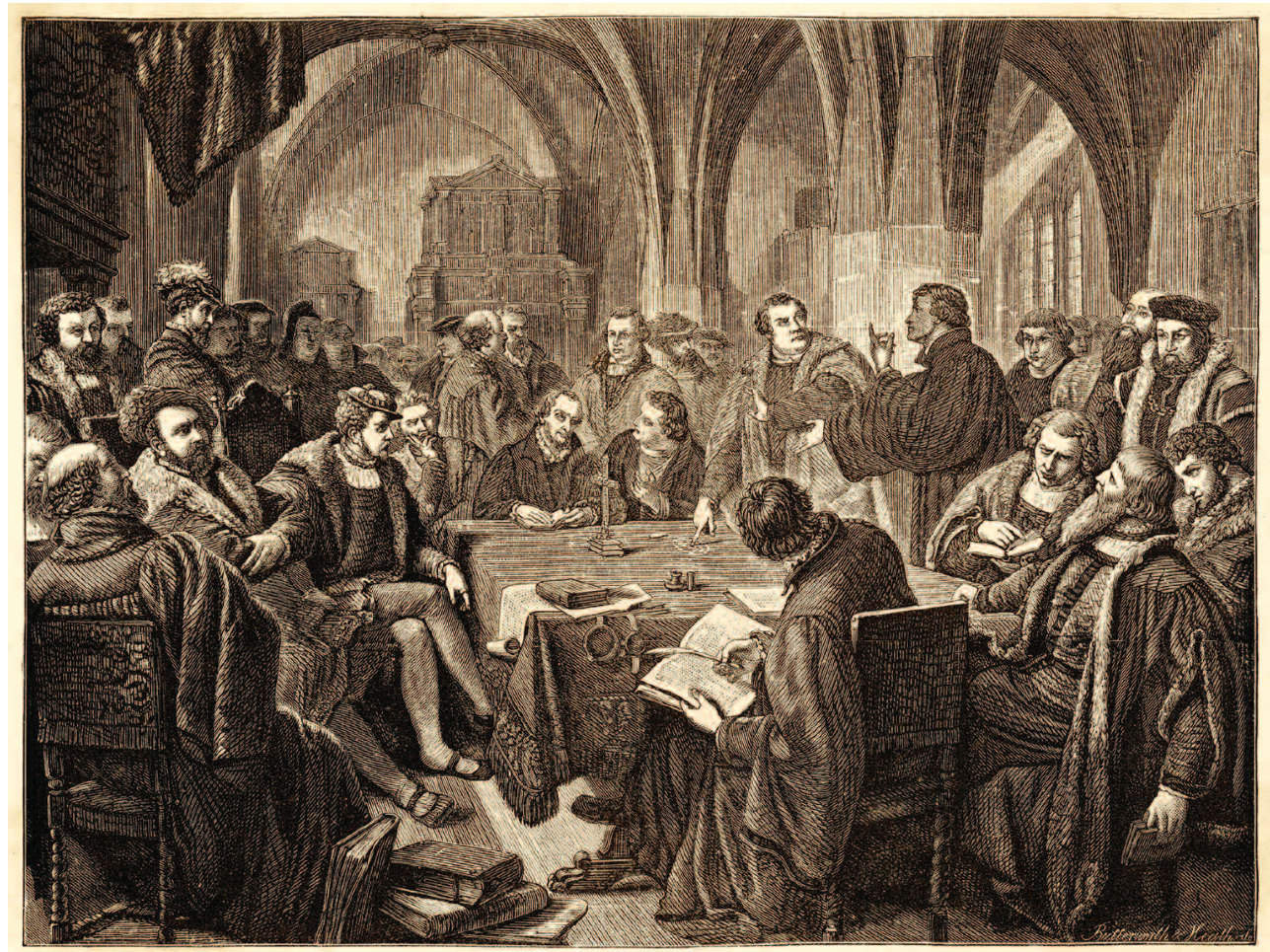

Marburg Colloquy, October 1529. Chronicle / Alamy Stock Photo (rights purchased)

Luther met with Ulrich Zwingli - a sort of minor church council - ending with Luther effectively excommunicating Swiss Protestants. He is said to have taken 
a piece of chalk and written on the table cloth Hoc Est Enim Corpus Meum (This is my body), saying, 'That is what Jesus meant - it is his body, and if you don't believe it you are not a Christian.'So radical incompatibility is there right at the height of Luther's career, and the Reformation would remain divided on these kinds of issues.

\section{Two visions in the English Reformation}

Now I want to go to the source of these Reformation changes in England in the 1520 s to consider some of the nature of these conflicts. I want to reflect on the tragic dimension of the original split as it worked out in the lives of two great Tudor figures: Thomas More and William Tyndale.
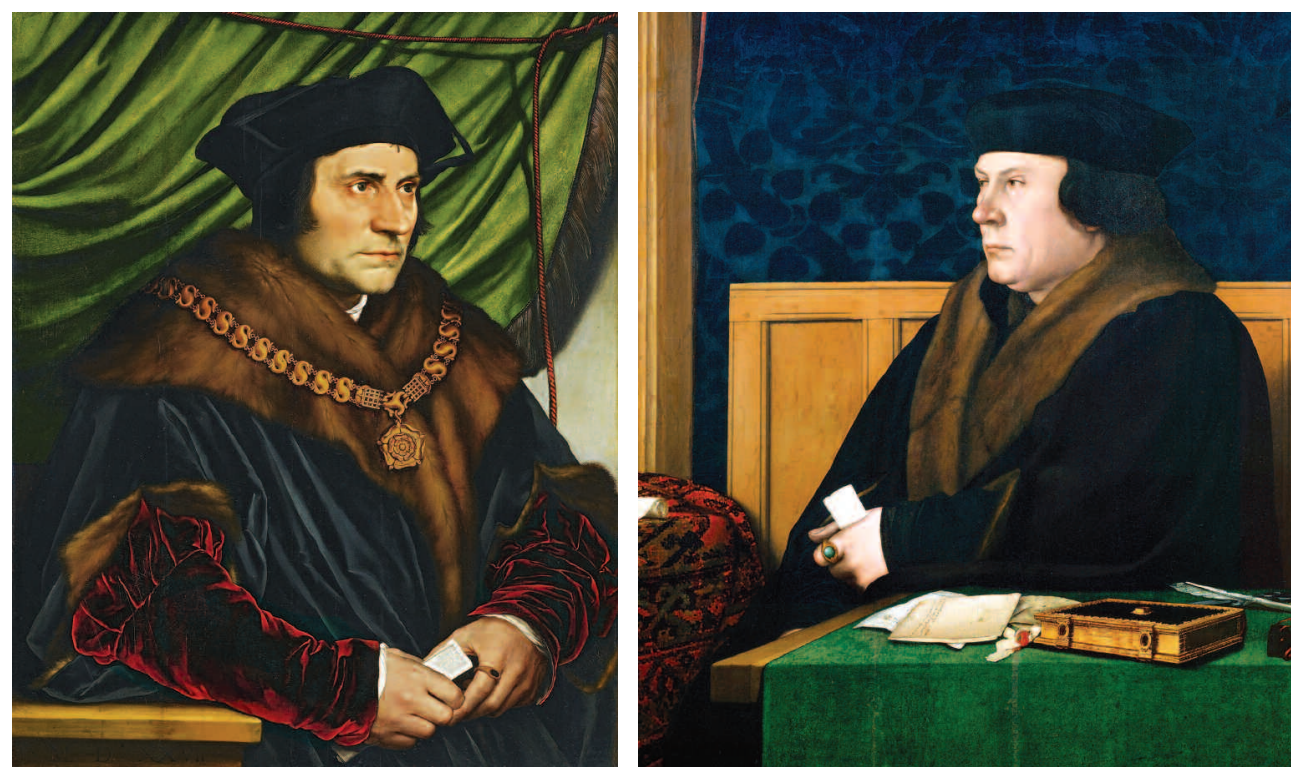

(left) Sir Thomas More, Hans Holbein (1527). The Artchives / Alamy Stock Photo (right) Thomas Cromwell, Hans Holbein (1532-33). Ian Dagnall / Alamy Stock Photo (rights purchased)

These are the two famous Holbein portraits from the Frick Collection in New York. They hang on either side of a fireplace in the main exhibition room, glaring at each other. It is really extraordinary to be in that relatively small space with these two amazing mesmerising pictures. They are utterly different personalities. 
More's reputation has taken the most tremendous hammering in recent years. More used to be thought of as a man for all seasons as portrayed by Paul Scofield, and that's a view still current among Roman Catholics. In 2012, the English Roman Catholic hierarchy issued a prayer card with a prayer about religious freedom, containing the words, 'Saint Thomas More, patron of religious freedom, pray for us.' On 31 October 2000, Pope John Paul II proclaimed More the patron saint of statesmen and politicians and, as was customary, the Pope preached a homily on that occasion, subsequently issued as an apostolic letter. ${ }^{1}$ Some months before the event, a draft of that homily was sent to me via the Cardinal Archbishop of Westminster for advice and correction. I was never told who had written the first draft, but the text was riddled with errors. The author was under the impression, for example, that More's favourite child and confidante was his son John, rather than, as was the case, his beloved daughter Margaret. But apart from the factual howlers, the text laid heavy stress on More's belief in the absolute sovereignty of conscience, very much in the manner of Bolt's Man for All Seasons. It said not a word about More's activities both as vehement polemicist and as the Crown's chief law officer in practical action against heresy and heretics. I wrote a long, detailed and very urgently phrased commentary on the draft, pointing out the errors and urging the Vatican to include in the text a frank admission of these unpalatable aspects of More's activities as 'hammer of the heretics'. Somewhat to my surprise the comments had some effect. The howlers duly disappeared, the section on conscience wasn't radically remodelled, but at the end of the key paragraph it did include an admittedly diplomatically vague allusion to More's anti-heretical activities. The text now reads:

it was precisely in defence of the rights of conscience that the example of Thomas More shone brightly. It can be said that he demonstrated in a singular way the value of a moral conscience which is 'the witness of God himself, whose voice and judgment penetrate the depths of man's soul' (Encyclical Letter, Veritatis Splendor, 58), even if, in his actions against heretics, he reflected the limits of the culture of his time. ${ }^{2}$

It was something, at any rate, to have gained some concession to reality.

Now, I want to say a little bit about More's activity. I don't have time on this occasion to go into a whole amount of detail. Largely because of the activities of my friend Hilary Mantel in Wolf Hall and Bring Up the Bodies, enormous 
fictional force has been given to a historical case that More was a man who betrayed his early beliefs by becoming a bigoted and cruel persecutor of other people. That's basically the figure who was portrayed so marvellously by Anton Lesser in the television series. The material that Hilary Mantel worked on was largely contained in Foxe's Book of Martyrs and alleged that More had tortured prisoners in his own house in Chelsea, and had condemned and then handed them to death. In fact he never condemned anyone to death and he vehemently and in detail categorically denied ever torturing anyone. But the worst thing you can do when you're accused of some mishap is to deny it because people say, 'Well, he would say that, wouldn't he.' So the canard stuck. But there is no doubt that if More didn't torture heretics - as he would have called them - he did relentlessly pursue people bringing Protestant books into England; he confiscated and saw to the burning of such books; and he particularly targeted his activities against William Tyndale and his followers. More believed that Tyndale was a demonic figure who was ruining souls.

Now, Tyndale, of course, was not a demonic figure. He was the greatest biblical translator who's ever worked in English. Till very recently all English translations of the Bible were indebted to the work he carried out in the 1520s and 30s. He was a translator of transcendent genius. Just think of the phrases that he coined which have gone on ringing through Bible translations ever since:'the last shall be first and the first shall be last'; 'many are called but few are chosen'; 'under the sun'; 'signs of the times'; 'Let there be light'; 'My Brother's Keeper'; 'lick the dust'; 'fell flat on his face'; 'The Land Of The Living'; 'pour out one's heart'; 'The apple of his eye'; 'Flesh pot'; 'Go the extra mile'; 'The parting of the ways'. He's a great creator of the English language, comparable with Shakespeare. And his little translation of the Bible was innovatory in other ways too; it's not just the genius of the language. Tyndale's New Testament of 1524 was the first New Testament in any European vernacular that you could put in your pocket. It was a little book, easy to smuggle, easy to carry. There is most likely only one complete copy surviving: they were said to have been bought up by the Bishop of London, Cuthbert Tunstall, Thomas More's friend. Tyndale used the money from the purchases to print a better edition. Tunstall burned them, of course. Tyndale himself ended by being burned - though not alive. He was mercifully strangled on the scaffold before they burned him - that's how they did it on the continent, the English practice was much more savage. He was executed the year after Thomas More was executed.

Why was More so antagonistic to Tyndale? In a way, he shouldn't have been. More was part of a great reforming generation of Catholics. He was the closest 
friend of Desiderius Erasmus, formerly a professor in this University of Cambridge. Erasmus, in many ways, initiated the process which Luther took up and which Tyndale dedicated his life to. Erasmus was a great biblical scholar and produced a daring new Latin edition, which established a printed Greek text of the New Testament. This, in many ways, began the theological landslide which turned into the Reformation by challenging traditional terminology, translating, for example, metanoia as 'repent' instead of 'do penance'. In all sorts of ways, Erasmus was a very radical figure who in addition to his scholarship used his brilliance as a satirist to ridicule traditional religious practice like pilgrimage. More was an ardent supporter of Erasmus. Some of More's most important writings are in the first half of his career, and are a series of impassioned defences of Erasmus's biblical work and his religious satire, saying that you need Bible translations - and a variety of Bible translations, no less - and if they challenge the original terminology they are to be judged on scholarly terms, and so on. More leapt to Erasmus's defence. He himself, in the same year as the publication of Erasmus's New Testament (1516), had published his famous Treaties, a sort of satirical work of science fiction, a utopia in which he imagined a republic set in the South Atlantic which had never encountered Christianity and where there was a race of rational pagans who tolerated religious dissent. So in all sorts of ways it seems paradoxical that this man, within a matter of years - five or six years - should turn from being a defender of these radical new insights in religion, and particularly in biblical work, into being the hammer of heretics and in particular targeting Tyndale as a biblical translator. Why did he do that? More's change of heart, if that's how one wants to describe it, came from what he saw as the negative charge in the Reformation - this insistence that the Bishop of Rome was Antichrist, and what he perceived to be the consequences of that fundamental move. In one early Lutheran print, the pope is depicted as a wolf devouring a sheep, with attendant monks and friars, and Peter and Paul disowning him. The negative stance that the Reformation adopted towards the traditional faith of Christendom convinced More that here was a force that had to be stopped in its tracks.

Partly, this was to do with More's belief in law and order. He was eventually to become Lord Chancellor of England. He was a great and humane Lord Chancellor and a legal reformer. But he passionately believed in order and discipline. One of the things that alarmed him about the Reformation was its radical political implications. The German Peasants' Revolt in 1525 had traumatised the upper classes - the ruling classes - all over Europe: the prospect of the many-headed multitude in arms attacking their betters. In 
common with most educated people in Europe, More believed that the Peasants' Revolt had been triggered by Luther and the libertarian rhetoric of Luther's gospel tracts. For example, in his treatise On the Liberty of a Christian Man, Luther had taken the case of a woman who married a man who turned out to be impotent. She wanted children, so Luther says, 'Well, what should she do?' The pope would have her go through an ecclesiastical tribunal to get an annulment, and she would have to discuss intimate details of the bedroom in front of priests, in order to get a piece of paper declaring her free. But, says Luther, she is free. So she should go to her husband and say, 'Since you cannot give me children, let me go to your brother or some other man and sleep with him and I will not shame you. I will give the children your name.' But, Luther goes on, no red-blooded German man is going to agree to that. So, what should she do?'Well,' Luther says, 'she should pack her bags, go somewhere where she is not known, and get married again. ${ }^{3}$ It is that kind of stance that horrified a lawyer like More, and he believed that this urging - to cast law and order to the winds; take things into your own hands; bypass the law, the Church, Christian morality; do your own thing because you are free - had triggered the Peasants' Revolt and brought chaos into Europe.

Luther himself, of course, notoriously felt the Peasants' Revolt was a monstrous aberration, and famously said:

Therefore let everyone who can, smite; slay, and stab, secretly or openly, remembering that nothing can be more poisonous, hurtful, or devilish than a rebel. It is just as when one must kill a mad dog; if you do not strike him, he will strike you, and a whole land with you. ${ }^{4}$

And years later, he told his disciples in his Table Talk:

I, Martin Luther, slew all the peasants in the uprising, for I ordered that they be put to death; all their blood is on my neck. But I refer it all to our Lord God, who commanded me to speak as I did. ${ }^{5}$

More felt some of the same vehemence that Luther felt towards the rebels, and towards the new ideology which he felt had caused the rebellion. In the year that More was arrested and taken to the Tower in London, radical Anabaptist Protestant forces had seized the city of Münster and introduced polygamy. John of Leiden, who became the ruler of the city, had 15 wives, one of whom he publicly beheaded himself because she disobeyed him. Lutheran and 
Catholic armies joined together to besiege the city and liberate it from this rebellion. The leaders were hanged up in cages, which are still on the tower of Münster Cathedral.

More's horror at the chaos that the Reformation had unleashed is explicable in terms of his own time. More than that, one of the consequences of the Reformation in the early 1520 s was a great wave of iconoclasm.

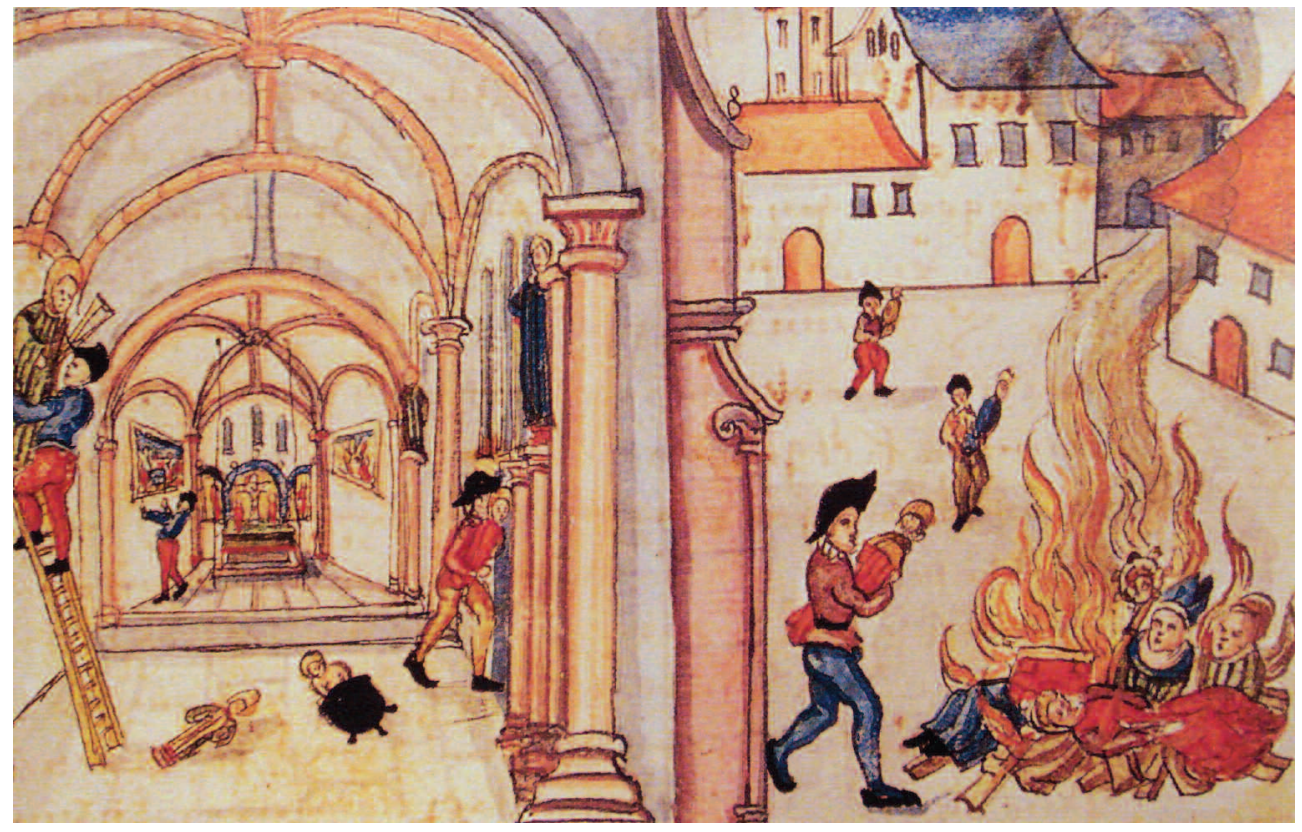

'Destruction of icons in Zurich 1524' (Anon.). ART Collection / Alamy Stock Photo (rights purchased)

This is a portrayal of the cleansing of the churches of images in Zurich in the early 1520 s, including the pulling down of wayside crosses and the smashing of images. One must remember that the cult of images was something which was really very strong throughout Catholic Europe at the time, and the impact of these desecrations is hard to overemphasise. Imagine somebody coming into your house and taking your wedding photographs, all the pictures of your dead mother and father, and tearing them up or urinating on them and burning them - it is that kind of horror. The violence involved is psychologically disturbing. If you want to see it for yourself go into the Lady Chapel at Ely that ruined space where the greatest collection of late Gothic sculpture in Europe was literally pulverised with hammers in the 1540 s. Although this was after More's death, he nevertheless knew it was happening all over Europe and often mentions it. 
So the point I want to make is that here, on the one hand, is Tyndale, motivated and driven by the desire to liberate God's word, to let the boy at the plough have as much knowledge of the gospel - if not more - than the theologians or the bishops or the pope, and by a sense that the Christian past had been one great conspiracy to lock up the word of God in the hands of experts and priests. It must now be let loose. On the other hand is More, a man equally committed to Christian truth and Christian reform, who believed that the way in which this word had been let loose had actually led to chaos and anarchy and murder. More's polemical writings are full of very powerfully evocations of the ruin which he believed the Reformation had wrought in Germany,

where their sect hath already foredone the faith, pulled down the churches, polluted the temples, put out and spoiled all good religious folk, joined friars and nuns together in lechery, despited all saints, blasphemed our blessed Lady, cast down Christ's cross, thrown out the Blessed Sacrament, refused all good laws, abhorred all good governance, rebelled against all rulers, fall to fights among themself, and so many thousand slain, that the land lieth in many places in manner desert and desolate. ${ }^{6}$

For More and Erasmus, Luther's teaching on predestination seemed to strike at the heart of all Christian virtue. They had preached a moral reform of Christendom - the cleansing of the Church from corruption and from the sale of things like indulgences, from bad behaviour among the clergy, from Christian laxity - and they urged people to reform their lives by living the gospel. Luther's message was that human beings are not free to do this - their wills are not free. Faith is a gift. Luther used metaphors, for instance saying that man before justification is like a corpse, and he can do nothing to earn his own justification. The technical debates that lay behind those kinds of vivid phrases would eventually get sorted out. But at the time, to people like More, it sounded as if Luther was preaching a kind of desperation, saying, 'You're not free to be good.' Above all More believed that people like Tyndale were motivated by pride.

Tyndale could see no good in More. More could see no good in Tyndale. And both of them, of course, within a year of each other, fell foul of the respective authorities in the countries in which they were living; both of them died for their understanding of the Christian faith. Of course, those executions in the 1530 s would be ramified in the hundred and fifty years which followed. 
CThe burning of Tharchbifhop of Gant, D. Tho, Cranmer in the town dich at Oxford, with his liand firft thruft into the fyre, wher Wich he lubicribed before.

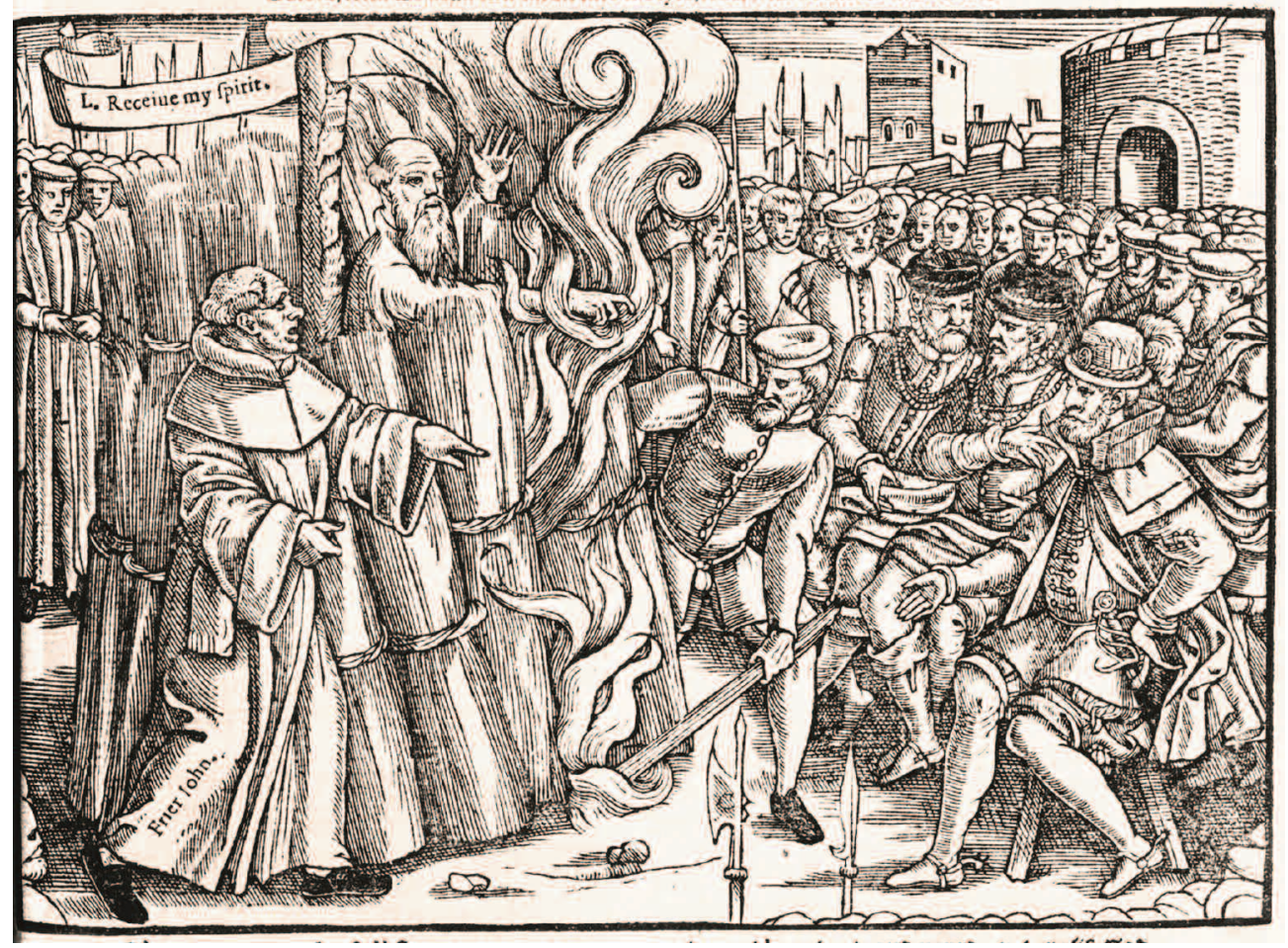

Execution of Archbishop Cranmer, woodcut from from Foxe's Book of Martyrs.

World History Archive / Alamy Stock Photo (rights purchased)

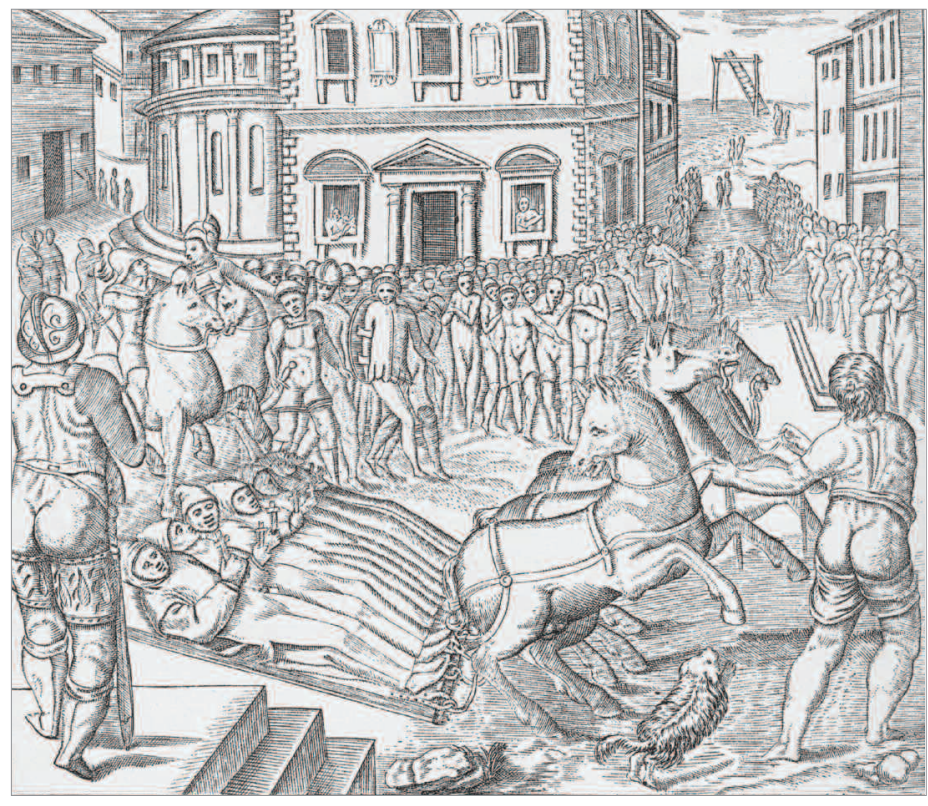

Execution of

Carthusian monks at Tyburn, 1535. Artist: Nicolas Beatrizet (1904). They resisted the royal supremacy in England under Henry VIII and were brutally hung, drawn and quartered after being starved. Heritage Image Partnership Ltd I Alamy Stock Photo (rights purchased) 
One can multiply the atrocities on both sides of the Reformation divide, not just the persecution of individuals, but also the chaos of war. The long legacy of this was the mutual excommunication and mutual hatred of Catholic and Protestant camps in our history in these islands, at times taking the form of the 'No Popery'.

\section{Two visions of the Reformation legacy}

I said at the beginning of this talk that I wanted to pick up the 'two visions' theme by referring to the work of two very good contemporary historians: Alex Ryrie - a former Methodist who's now an Anglican - who teaches at Durham; and Brad Gregory, who is the head of Arts and Humanities Research at Notre Dame University. They have both written very good general books on the legacy of the Reformation. Brad Gregory published his enormous book called The Unintended Reformation in 2012. He's a particular authority on the Anabaptists and has written the best book on sixteenth-century religious persecution, both Catholic and Protestant. His particular interest is in the Anabaptist movement; that is, the radical wing of the Reformation. Alec Ryrie is a special authority on the early Tudor Reformation and on the Scottish Reformation. He has just published a book which is a very good read indeed, called Protestants - plural. Brad Gregory is a Roman Catholic, and Alec Ryrie is an Anglican lay preacher, formerly a Methodist lay preacher.

Brad Gregory is in no doubt that the outcomes of the Reformation were, on the whole, negative. He shares some of the perceptions, if not the vehemence, of Thomas More. According to him, the principle of sola scriptura and the rejection of the Church's teaching authority in the end led to what he calls the 'market of values' in which all certainties are dissolved. The abolition of the vowed religious life of monks and nuns removed a powerful institutional witness to Christian ambivalence about material prosperity and opened the door to the acquisitive society. By contrast, the intractability of post-Reformation religious disagreements, among Protestants especially, contributed to the emergence of societies which found their rationale in purely materialistic values, such as the protection of property, or the contractual guarantee of the rights of the individual. In the pioneering early modern secular states, especially the Dutch Republic, he argues that men and women decided to stop killing each other over religion and go shopping instead. In the long run, because there was no universally accepted norm for truth, religion became a private 
matter. And this privatisation of religion became one of the building blocks of Enlightenment social theory. So Thomas Jefferson can say, 'It does me no injury for my neighbour to say there are twenty gods or no god: it neither picks my pocket, nor breaks my leg.' ${ }^{8}$ Here, Brad Gregory thinks, is the origin of a rootless modern hyperpluralism in which there is no objective basis for shared value, and in which good and bad become matters of arbitrary personal preference. Or as Gregory, who is an American, puts it, 'Whatever'.

Gregory's study of the Anabaptist movement led him to believe that our perception of the Reformation as having given rise to a different kind of religion is misleading, because mainstream Protestantism is only mainstream from a particular perspective. There were just as many radical fringe groups as there were of so-called mainstream Protestants. These groups would eventually get suppressed by power - by political power - but there is no internal logic in the Reformation which would make one Reformation view normative. People go to the Bible and they find what they find, but they don't all find the same thing.

By and large, Alec Ryrie accepts broadly the same picture of the radical incompatibility of competing Protestant views of the world. So, in his book Protestants, he doesn't call it 'Protestantism' because he doesn't think there is such a thing as Protestantism; there are just 'Protestants'. And Protestants, he thinks, are characterised by two things: they are lovers and they are fighters. They are lovers in that they are motivated by a desire to find and love God, and to love the Scriptures. And they are fighters because they don't agree with anybody else who's doing the same thing. So his book is a sort of unfolding of the history of Protestantism over four centuries, arguing that there isn't a common stream, not even, for example, the Bible - because there are now forms of Protestantism in Africa, just as there were in seventeenth-century England, in which the Bible is not treated as a sacrosanct book. There is a famous story about George Fox at Swarthmoor Hall coming in on a Puritan Bible study. He sat and listened as people quoted the Scriptures, then stood up and said, 'You will say, Christ saith this, and the apostles say this; but what canst thou say?' ${ }^{\prime}$ The sense that the heart of the gospel is the Spirit within, and neither a text nor a man in a dog collar telling you what the text means, is a very radically solvent principle. Ryrie cheerfully embraces this and says that Protestantism is constantly changing. It has got a huge vigour which springs from the twin roots of Protestants being lovers and fighters. There will never be a normative form of Protestantism; there will never be Protestant unity; there will never be Protestant-Catholic unity; because the fighting is intrinsic - it is there from the very beginning. It started with Luther burning the pope's 
bull of excommunication - defiance is in the genes. But such defiance is also part of its vigour and why it has made the modern world the way it is. The subtitle of Ryrie's book is 'the faith that made the modern world'. Brad Gregory thinks it was indeed the faith that made the modern world - but that, for him, is very bad news. So, two contrasting visions.

\section{Conclusion}

One of the reasons More detested Protestantism was that it challenged the traditional faith of the Church. By that he did not mean 'what the pope taught'. More never justifies church teaching by appealing to the pope. He appeals to the common faith of ordinary people: what your father and mother believed, and what their father and mother believed, and what their father and mother believed. He understood the Church as the common corps of Christendom, and he thought that that Church is holy. So he was prepared to give folk religion the benefit of the doubt because he thought behind it was a deep instinct of holiness which had to be respected, and before which one must be humble. This is one of the areas in which he disagreed with his friend Erasmus. On the other hand, Luther and Tyndale believed that this so-called common corps of Christendom had been massa damnata - it had been a great thousand-year journey into error - and armed with the Bible in your hand you could see through it.

Those two visions end up with different pictures of what the Church is. At its organised Roman Catholic end, it is a great institution, a global Church. The Second Vatican Council, for instance, is a great reforming Council, but it goes about it as a great unitary organisation, hierarchically organised. At the other end, there is an imagining of the Church as made up of small covenanted groups of people inspired by the Spirit, getting their truth neat from the Bible. That legacy has gone on deepening, and has led to radically different forms of Christian expression. They overlap: in the less desirable Roman Catholic churches these days you can sing gospel choruses at Mass, and you can wander into Anglican churches which are indistinguishable from the Vatican except that the Latin is pronounced better.

Of course, many of the great ruptures in theology that started this whole thing off have been healed. Last year, the Evangelical Lutheran Church of America declared that on all the major Reformation issues there are now no churchdividing differences between Catholics and Lutherans. But I think, sadly, both 
Ryrie and Gregory are right in seeing the ruptures of the Reformation as ineradicable. There may be local unions, and I think one of the most encouraging features of ecumenism in the twentieth and twenty-first centuries has simply been the laying down of arms and the recognition of Christian truth in each other - what Paul Murray at Durham calls 'receptive ecumenism', attending to what God has given to other churches as well as to other individuals and seeing how those things can be reflected in church relations. But I think the Reformation does represent one of the great fractures in history which cannot be gone behind. The rivers flow in directions which are not likely to flow together at any foreseeable point in the future, which is perhaps a sobering note on which to end.

\section{Notes}

1. 'Apostolic Letter issued Motu Proprio Proclaiming Saint Thomas More Patron of Statesmen and Politicians', Pope John Paul II, http://w2.vatican.va/content/johnpaul-ii/en/motu_proprio/documents/hf_jp-ii_motu-proprio_20001031_thomasmore.html (accessed 21 August 2017).

2. 'Apostolic Letter', §4.

3. Martin Luther, The Babylonian Captivity of the Church, §6.24 and 25.

4. Martin Luther, Against the Robbing and Murdering Hordes of Peasants.

5. Martin Luther, Table Talk.

6. Thomas More, Dialogue Concerning Heresies, chapter 14.

7. For instance, in 1988, when the late Lord Paisley heckled Pope John Paul II at the United Nations.

8. Thomas Jefferson, Notes on Virginia.

9. Quoted in Quaker Faith and Practice, 19.07. 